\title{
COOPERATIVE LEARNING SEBAGAI STRATEGI PENANAMAN KARAKTER DALAM PEMBELAJARAN PENDIDIKAN PANCASILA DAN KEWARGANEGARAAN DI SEKOLAH
}

\author{
M. Lutfi Baehaqi \\ Universitas Negeri Yogyakarta \\ lutfibaehaqi09@gmail.com
}

\begin{abstract}
Abstrak: Pendidikan Pancasila dan Kewarganegaraan (PPKn) merupakan mata pelajaran yang memiliki misi sebagai pendidikan karakter, nilai dan moral Pancasila, pengembangan komitmen terhadap Negara Kesatuan Republik Indonesia (NKRI), dan penghayatan terhadap filosofi Bhinneka Tunggal Ika. Peran PPKn adalah menanamkan nilai-nilai karakter yang luhur kepada peserta didik agar menjadi manusia yang cerdas dan baik, sesuai dengan nilai-nilai Pancasila dan UUD Negara Republik Indonesia Tahun 1945. Kajian ini bertujuan mendeskripsikan model cooperative learning dalam pembelajaran Pendidikan Pancasila dan Kewarganegaraan sebagai strategi penanaman karakter di sekolah. Penelitian ini merupakan penelitian deskriptif kualitatif. Pengumpulan data menggunakan studi kepustakaan yang berupa buku, jurnal, artikel, dokumen, dan lain sebagainya. Data yang terkumpul dianalisis secara kualitatif dengan cara berpikir induktif. Hasil penelitian menunjukkan bahwa pendidikan karakter dalam pembelajaran PPKn harus sesuai dengan karakteristik pembelajaran PPKn dan tujuan pendidikan karakter, memiliki prosedur yang mengorganisasikan pemahaman serta pengalaman belajar peserta didik dan harus terintegrasi dengan lingkungannya, mampu mengintegrasikannya dengan fenomena sosial atau fenomena kewarganegaraan. Model cooperative learning dalam pembelajaran PPKn harus logis dan memiliki landasan berpikir yang konkret, mencakup konteks akademik sesuai dengan materi dan kompetensi yang hendak dicapai, serta mendorong peserta didik untuk berperan aktif, berpikir kritis, memaksimalkan bakat, minat, dan potensinya.
\end{abstract}

Kata Kunci: Pendidikan Pancasila dan Kewarganegaraan, penanaman karakter, pembelajaran kooperatif.

\section{COOPERATIVE LEARNING AS CHARACTER PLANTING STRATEGY IN LEARNING OF PANCASILA AND CIVIC EDUCATION IN SCHOOLS}

\begin{abstract}
Abstrack: Pancasila and Civic Education (PPKn) is a subject that has a mission as character education, values and morals of Pancasila, the development of a commitment to the Unitary State of the Republic of Indonesia (NKRI), and appreciation of the philosophy of Unity in Diversity. The role of PPKn is to instill noble character values to students to become intelligent and good human beings, in accordance with the values of the Pancasila and the 1945 Constitution of State of the Republic of Indonesia. This study aimed to describe the
\end{abstract}


cooperative learning model in learning Pancasila and Civic Education as a character planting strategy in school. This research is a qualitative descriptive study. Data collection used library research in the form of books, journals, articles, documents, and so forth. The collected data is analyzed qualitatively by inductive thinking. The results showed that character education in PPKn learning must be in accordance with the characteristics of PPKn learning and character education objectives, have procedures that organize students' understanding and learning experience and must be integrated with their environment, able to integrate it with the social or citizenship phenomena. The cooperative learning model in learning PPKn must be logical and have a concrete foundation for thinking, covering the academic context in accordance with the material and competencies obtained, and encouraging students to play an active role, think critically, maximize their talents, interests, and potencies.

Keywords: Pancasila and Civic Education, character planting, cooperative learning.

\section{PENDAHULUAN}

Pendidikan Pancasila dan

Kewarganegaraan (PPKn) merupakan salah satu mata pelajaran yang memiliki peran penting dalam membentuk kepribadian peserta didik. Hal ini sesuai dengan apa yang telah dinyatakan Kementerian Pendidikan dan Kebudayaan (2014:1) bahwa PPKn merupakan mata pelajaran yang memiliki misi sebagai pendidikan karakter, nilai dan moral Pancasila, pengembangan komitmen terhadap Negara Kesatuan Republik Indonesia (NKRI), dan penghayatan terhadap filosofi Bhinneka Tunggal Ika. Berkaitan dengan pendidikan karakter, peran PPKn melalui pembelajarannya adalah menanamkan nilai-nilai karakter yang luhur. Tujuan pembelajaran PPKn yaitu menjadikan peserta didik menjadi manusia yang cerdas dan baik serta demokratis sesuai dengan nilai-nilai
Pancasila dan UUD Negara

Kesatuan Republik Indonesia

Tahun 1945 yang meliputi penguasaan pengetahuan (knowledge), sikap dan nilai (attitudes and values), keterampilan (skills) (Hamisa \& Murdiyono; 2018; Pangalila, 2017; Akbal, 2017; Muhibbin \& Sumarjoko, 2016). Dari hal tersebut dapat dipahami bahwa PPKn merupakan mata pelajaran yang memfokuskan dalam hal pembentukan warga negara yang dapat memahami dan menjalankan hak serta kewajibannya sebagai manusia yang berpengetahuan, berketerampilan, berkarakter luhur, dan demokratis.

Menurut Wahab (1995)

Pendidikan Pancasila dan

Kewarganegaraan (PPKn) adalah salah satu program pendidikan nasional dengan berdasarkan atas nilai-nilai Pancasila dan Undangundang Dasar 1945 sebagai sarana dalam menumbuhkan, membentuk, menguatkan, serta melestarikan 
nilai-nilai moral dan karakter yang luhur pada peserta didik. Selanjutnya, nilai-nilai tersebut dapat melekat menjadi jatidiri dan karakter pada setiap orang yang diamalkan dalam kehidupan sehari, baik dalam kehidupan beragama, berbangsa dan bernegara.

Pada kenyataannya PPKn di sekolah dianggap oleh sebagian peserta didik merupakan mata pelajaran yang membosankan. Hal tersebut tersebut dikarenakan oleh beberapa faktor, salah satu faktor yang sering terjadi adalah faktor guru PPKn penyampaian materi dengan cara konvensional, seperti halnya terus-menerus memberikan ceramah, pembelajaran hanya terfokus pada guru saja. Guru dijadikan satu-satunya sumber belajar, sehingga ketika ia berbicara di depan kelas, peserta didik harus mendengarkannya. Dari hal tersebut sebagai pendidik dan pengajar, guru dituntut mengembangakan dan menggunakan kemampuan keprofesionalannya dalam merencanakan, melaksanakan, dan mengevaluasi pembelajaran yang dilaksnakan di dalam kelas.

Berkaiatan dengan tujuan PPKn yang telah dijelaskan tersebut, maka pencapaian tujuan pendidikan karakter akan sulit diraih jika hanya menggunakan cara-cara konvensional. Oleh karena itu, diperlukan suatu kegiatan pembelajaran dengan adanya interaksi timbal-balik antara peserta didik dan guru, sehingga dari hal tersebut akan tercipta kegiatan pembelajaran yang terarah dan aktif. Oleh karena itu, tugas guru sebagai pendidik memiliki keharusan mampu mengolah dan memilih metode serta strategi pembelajaran yang sesuai dalam menciptakan suasana belajar yang dinamis. Ada banyak cara yang dapat dilakukan oleh guru dalam mewujudkan tujuan PPKn sebagai salah satu penanaman karakter kepada peserta didik. Oleh karena itu, sebagai pendidik dan pengajar guru wajib merencanakan, melaksanakan, dan mengevaluasi pembelajaran secara matang. Salah satu cara agar pembelajaran yang dilakukan berdampak dalam menanamkan nilai-nilai karakter yang terintegrasi dengan pembelajaran PPKn, yaitu dengan menerapkan model Cooperativ Learning .

Model pembelajaran kooperatif adalah bentuk model pembelajaran yang digunakan dalam menciptakan kegiatan pembelajaran yang berpusat pada peserta didik (student oriented), terutama dalam mendorong partisipasi peserta didik dalam pembelajaran (Isjoni, 2009:16). Hal tersebut sesuai dengan apa yang telah diungkapkan Martati (2010:15) mengenai tujuan pembelajaran kooperatif yang sedikitnya memiliki tiga tujuan penting, yaitu: pertama, meningkatkan kegiatan atau partisipasi peserta didik; kedua, membiasakan terjalinnya sikap toleransi; dan ketiga membiasakan peserta didik untuk melakukan perilaku kerja sama satu sama lain.

Penerapan berbagai metode dalam pembelajaran PPKn sangat diperlukan terutama metode yang dapat memfasilitasi peserta didik agar mengikuti pembelajaran secara 
aktif dan tumbuh kreativitas dan keterampilannya. Di sinilah arti pentingnya kajian ini yang mencoba mengungkap apakah metode atau strategi cooperative learning dalam pembelajaran PPKn efektif untuk penanaman karakter bagi peserta didik di sekolah. Penerapan model cooperative learning (pembelajaran kooperatif) selain mendorong peserta didik untuk berpartisipasi aktif, juga diharapkan tercipta komunikasi yang multiarah. Artinya, komunikasi yang tercipta bukan hanya antara peserta didik dan guru saja, melainkan juga dengan teman atau peserta didik lainnya. Hal inilah yang kemudian akan mengubah pemikiran atau mage peserta didik bahwa PPKn dianggap sebagai mata pelajaran yang membosankan. Dengan metode pembelajaran kooperatif diharapkan pembelajaran PPKn menjadi pembelajaran yang menarik dan menyenangkan.

\section{METODE}

Penelitian ini menggunakan
metode deskriptif kualitatif.
Pengumpulan data dilakukan
dengan studi pustaka (library
research). Studi pustaka dilakukan
dengan membaca, menelaah, dan
mengkaji berbagai sumber literatur,
baik buku, jurnal, artikel, dokumen,
dan lain sebagainya yang terkait
dengan permasalahan yang dikaji,
yakni penerapan metode
cooperative learning dalam
pembelajaran PPKn untuk
penanaman karakter peserta didik
di sekolah.

Data yang diperoleh dari pembacaan terhadap berbagai sumber literatur yang terkait dengan permasalahan kemudian dianalisis secara kualitatif denga cara berpikir induktif. Dengan analisis kualitatif, diharapkan penelitian ini menghasilkan simpulan yang sesuai dengan permasalahan yang dikaji.

\section{HASIL DAN PEMBAHASAN}

Fokus kajian penelitian ini mengenai penggunaan model pembelajaran kooperatif dalam pembelajaran PPKn dalam rangka penanaman karakter peserta didik di sekolah. Secara berturut-turut di bawah ini akan diuraikan pengertian model pembelajaran kooperatif, karakteristik model pembelajaran kooperatif, tipe-tipe model pembelajaran kooperatif, dan penggunaan model pembelajaran kooperatif yang tepat dalam pembelajaran PPKn untuk penanaman karakter pada peserta didik di sekolah.

\section{Pengertian Model Pembelajaran Kooperatif \\ Trianto \\ (2010:}

menjelaskan bahwa model pembelajaran merupakan sebuah perencanaan dan pola yang dipakai untuk dijadikan pedoman merencanakan pembelajaran. Hal ini mengacu pada pendekatan pembelajaran yang di dalamnya terdapat tujuan, tahap, lingkungan, dan pengelolaan pembelajaran. Konsep ini dikuatkan oleh Shoimin (2014:24) yang menegaskan bahwa fungsi model pembelajaran sebagai pedoman guru dalam melaksanakan 
pembelajaran. Istilah model ini tentunya berbeda dengan istilah metode.

Metode menurut Djamarah (2008: 46) diartiakan sebagai cara dalam mencapai tujuan. Dalam lingkup pembelajaran, metode sering digunakan guru secara bervariasi untuk mencapai kompetensi pembelajaran, sebagai bentuk dari hasil belajar. Dapat disimpulkan bahwa model pembelajaran merupakan prosedur yang memiliki pola berurutan yang digunakan dalam rangka mewujudkan tujuan pembelajaran. Model mencakup strategi, teknik, metode, bahan, media, dan alat penilaian pembelajaran. Selanjutnya, metode merupakan bagian dari model, yaitu cara yang dipakai dalam berinteraksi antara guru dengan peserta didik, dalam rangka mencapai tujuan pembelajaran.

Salah satu model pembelajaran yang sering digunakan dalam kegiatan pembelajaran adalah cooperative learning, yang tidak lain berasal dari dua kata yaitu coopertaive dan learning. Hasan (1996) menyebutkan bahwa kata cooperative mengandung makna bekerja sama dalam mewujudkan suatu tujuan tertentu. Sedangkan, learning dapat diartikan sebagai pembelajaran. Dari makna-makna tersebut, dapat disimpulkan bahwa cooperative learning atau pembelajaran kooperatif dapat dipahami sebagai pembelajaran yang dilaksanakan dengan caracara bekerja sama atau berkelompok antarsesama peserta didik.
Pengertian pembelajaran kooperatif di atas senada dengan pendapat Solihatin (2013:102) yang juga menegaskan bahwa pembelajaran kooperatif merupakan salah satu model pembelajaran yang dilaksanakan dalam kegiatan belajar mengajar, yang di dalamnya para peserta didik berkerja sama dalam kelompok yang terdiri atas 4-6 anggota. Selanjutnya, dikemukakan juga bahwa terwujudnya tujuan dari proses pembelajaran berkelompok tersebut juga sangat dipengaruhi oleh kemampuan dan partisipasi setiap anggota kelompok, baik sebagai individu maupun sebagai satu kesatuan.

Pada intinya, pembelajaran kooperatif bukan hanya sekedar model pembelajaran saja. Interaksi antarpeserta didik dan dengan guru dalam pembelajaran ini sangat ditonjolkan. Selain itu, pembelajaran kooperatif akan mendorong peserta didik agar terbiasa melakukan suatu sikap dan perilaku bekerja sama, bergotong royong, mufakat, menghargai toleransi, saling menghormati, dan sebagainya. Selanjutnya, sikapsikap tersebut yang diwujudkan dalam sebuah pola hubungan kerja yang dimaksud, kemudian diharapkan memunculkan persepsi yang baik dari apa yang peserta didik peroleh melalui pembelajaran kooperatif, memaksimalkan potensi diri, baik dalam berpendapat atau mengemukakan gagasan maupun mencari jalan keluar dalam mengatasi persoalan.

Solihatin (2013:103) juga menjelaskan bahwa model pembelajaran kooperatif digunakan 
berdasarkan asumsi dalam kehidupan masyarakat. Artinya, model pembelajaran kooperatif ini dalam pelaksanaannya di kelas merupakan bentuk penyederhanaan atau bagian dari kegiatan-kegiatan nyata dalam kehidupan masyarakat. Banyak perilaku masyarakat yang mengedepankan diskusi, mufakat, toleransi, dan sebagainya kemudian dibiasakan juga terhadap peserta didik dalam bentuk model pembelajaran kooperatif. Masih banyak para ahli yang berpendapat tentang model pembelajaran kooperatif yang pada prinsipnya hampir sama (Bodsworth, \& Goodyear, 2017; Leasa \& Corebima, 2017; Dyson \& Casey, 2016; Akçay, 2016; Maman \& Rajab, 2016).

Dari penjelasan di atas dapat disimpulkan bahwa diciptakannya model pembelajaran kooperatif memiliki tujuan yaitu membantu peserta didik dalam membentuk serta mengembangkan pengetahuan, sikap, dan perilaku sesuai kebutuhan dalam kehidupan nyata. Melaluinya, peserta didik akan bertambah kualitas diri, baik secara pemahaman maupun sikap dan aksi dalam kehidupan seharihari. Pola interaksi yang terjadi dalam model pembelajaran kooperatif yang cenderung mengedepankan kerja sama, toleransi, saling menghargai, dan mufakat akan melalui model pembelajaran ini akan melekat. Isjoni (2009: 27-28) menambahkan bahwa tujuan pembelajaran kooperatif yaitu: 1) memperbaiki hasil atau prestasi belajar peserta didik; 2) membiasakan sikap menerima perbedaan individu, yang secara luas meliputi berbagai hal, baik suku, agama, ras, dan budaya. Sedangkan dalam konteks pembelajaran, model pembelajaran kooperatif memberi kesamaan hak dan kewajiban bagi semua peserta didik, sehingga menimbulkan sikap saling menghargai dan menghormati; dan 3) mengembangkan perilaku sosial peserta didik, yaitu bekerja sama dan berkolaborasi dengan temannya. Lalu ditambahkan lagi oleh Surapranata (2010: 32) bahwa tujuan pembelajaran kooperatif pada dasarnya untuk membangun nilai-nilai demokrasi serta menumbuhkan sikap mampu bekerja sama dan sikap menghargai perbedaan pada peserta didik.

Tujuan-tujuan pembelajaran kooperatif di atas jelas sangat sesuai dengan tujuan mata pelajaran Pendidikan Pancasila dan Kewarganegaraan (PPKn) di sekolah. PPKn memiliki tujuan secara umum yaitu untuk membentuk generasi muda, khususnya peserta didik agar menjadi warga negara yang baik, cerdas secara akademik, namun juga memilki kepribadian luhur dalam pergaulan kehidupan seharihari, baik di rumah, di sekolah, maupun di lingkungan masyarakat.

\section{Karakteristik Kooperatif}

Pembelajaran

Pada dasarnya pembelajaran kooperatif dapat disandingkan dengan kerja kelompok, namun ada perbedaan yang mencolok dari keduanya. Pembelajaran kooperatif lebih bervariasi, sedangkan kerja kelompok cenderung bersifat tidak 
inovatif. Model pembelajaran kooperatif tidak hanya memiliki kelebihan dalam membantu peserta didik untuk memahami materi pembelajaran, akan tetapi juga memiliki fungsi agar peserta didik berpikir kritis, bekerja sama dan berinteraksi, serta membantu peserta didik lain yang mengalami kesulitan. Selanjutnya ada beberapa unsur yang menonjol dalam pembelajaran kooperatif. Menurut Isjoni (2010: 41) unsur-unsur tersebut meliputi: 1) positive interdependence atau hubungan timbal balik antarsesama anggota kelompok, yang berarti fokus keberhasilannya bukan terletak pada keberhasilan individu, tetapi keberhasilan kelompok; 2) interaction face to face, yaitu interaksi langsung antarpeserta didik; 3) tanggung jawab sebagai bagian dari kelompok, sehingga satu sama lain saling membantu; dan 4) perwujudan dari perilaku bekerja sama dalam memecahkan masalah. Pendapat ini diperkuat oleh beberapa ahli, seperti Slavin (2011), Akçay (2016), Dyson \& Casey (2016), dan Rahman, Ahmar, \& Rusli (2016).

Dari berbagai pendapat para ahli tersebut dapat disimpulkan bahwa karakteristik pembelajaran kooperatif yaitu: 1) adanya tujuan sebagai kelompok, bukan individu; 2) adanya pertanggungjawaban individu sebagai bagian dari kelompok; dan 3) adanya kesempatan yang sama bagi setiap individu baik sebagai bagian dari kelompok maupun bagi masingmasing kelompok. Jadi, pembelajaran kooperatif merupakan model pembelajaran yang diterapkan dalam bentuk kelompok yang masing-masing kelompok terdiri atas 4-6 orang anggota kelompok yang saling berinteraksi dan bekerja sama dalam proses pembelajaran. Model pembelajaran kooperatif cenderung mengedepankan sikap dan perilaku tanggung jawab, baik sebagai individu, bagian dari kelompok, maupun sebagai satu kesatuan kelompok dalam mewujudkan tujuan bersama yang hendak dicapai. Yang terakhir, dalam pembelajaran kooperatif terdapat kesempatan yang sama bagi individu atau kelompok dalam menyampaikan gagasan.

Dengan karakteristik model pembelajaran kooperatif seperti itu peserta didik akan mendapatkan motivasi belajar, berani mengemukakan pendapat, tumbuh sikap menghargai perbedaan pendapat, dan saling mendukung serta memperkuat pendapat rekannya. Selain itu, dalam pelaksanaan pembelajaran kooperatif biasanya peserta didik akan dihadapkan pada suatu masalah, sehingga hal dapat mendorong peserta didik untuk bekerja sama dan berpikir kritis dalam memecahkan masalah. Di samping karakteristik yang telah dijelaskan di atas, model pembelajaran kooperatif juga memiliki beberapa keunggulan, yaitu: 1) terciptanya ketergantungan antarpeserta didik yang bersifat positif; 2) adanya pengakuan dalam menanggapi perbedaan; 3) melaksanakan pembelajaran dengan model kooperatif, berarti telah melibatkan peserta didik dalam merencanakan 
dan mengelola kelas; 4) suasana kegiatan pembelajaran menjadi santai dan menyenangkan; 5) menumbuhkan interaksi dan komunikasi antarsesama peserta didik dan juga dengan guru; dan 6) adanya kesempatan yang sangat terbuka bagi setiap peserta didik dalam mengekspresikan emosi, pengetahuan, pengalaman peserta didik.

\section{Tipe-tipe Pembelajaran Kooperatif}

Ada banyak tipe dari model pembelajaran kooperatif yang sering digunakan dalam proses pembelajaran, berikut beberapa tipe pembelajaran kooperatif.

\section{Student Teams Achievement Divisions (STAD)}

Menurut Slavin (2011: 143), student teams achievement divisions (STAD) merupakan salah satu tipe pembelajaran kooperatif yang paling sederhana. Oleh karena itu, tipe pembelajaran ini dapat dipakai dan diterapkan oleh setiap guru, sekalipun itu merupakan guru yang baru menggunakan pembelajaran kooperatif. Tipe pembelajaran ini menempatkan peserta didik dalam kelompok kecil yang beranggotakan kurang lebih ada empat orang yang heterogen, baik dalam hal keterampilan dan pengetahuan, kinerja, jenis kelamin, maupun suku, agama, dan ras. Langkah pembelajaran tipe STAD ini diawali dengan guru menyajikan materi pembelajaran, kemudian peserta didik diarahkan untuk bekerja sama secara berkelompok untuk memahami apa yang telah dijelaskan guru. Gagasan dasar dari pembelajaran
STAD yaitu untuk memotivasi peserta didik agar saling mendukung dan membantu rekannya dalam memahami materi yang telah dipaparkan oleh guru. Antarsesama anggota kelompok harus saling mendukung satu sama lain dan memberikan partisipasinya secara baik. Hal ini memotivasi peserta didik bahwa dalam belajar juga memerlukan kerja sama, menghargai pendapat satu sama lain, serta berlatih dalam berpikir kritis dan memecahkan masalah.

Kelebihan tipe pembelajaran STAD ini juga diungkapkan oleh Isjoni (2010: 1), di antaranya: 1) menekankan peserta didik untuk saling berinteraksi satu sama lain; 2) saling memotivasi dan membantu dalam memahami materi pembelajaran agar mencapai prestasi kelompok dengan maksimal; dan 3) memberikan kesempatan terbuka bagi setiap peserta didik untuk saling memberikan kontribusi terhadap kelompoknya dengan cara memaksimalkan kemampuannya. Selain memiliki keunggulan, tipe pembelajaran STAD juga memiliki kekurangan seperti yang diungkapkan oleh Trianto (2009:70), antara lain alam berkelompok memerlukan adanya pengaturan tempat duduk untuk mengantisipasi adanya kekacauan, yang kemudian berpengaruh terhadap tercapainya tujuan dan keberhasilan pembelajaran kooperatif.

\section{Picture and Picture}

Kurniasih \& Sani (2015: 44) menjelaskan bahwa picture and picture merupakan tipe 
pembelajaran kooperatif yang menonjolkan adanya kelompok dengan media berupa gambar yang diurutkan, sehingga membentuk urutan yang teratur. Tipe ini juga lebih mengutamakan persamaan persepsi atau pendapat setiap peserta didik sebagai bagian dari satu kelompok, menekankan kerja sama dalam kelompok, serta mendorong peserta didik untuk kreatif. Menurut Huda (2014:239) tipe ini juga memiliki kelebihan dan kekurangan. Di antara kelebihan tipe pembelajaran picture and picture antara lain: 1) sebagai pendidik, guru akan lebih memahami kemampuan masingmasing peserta didik; 2) melatih peserta didik untuk berpikir logis dan sistematis; 3) memberikan kebebasan sudut pandang peserta didik; 4) memotivasi peserta didik dalam mengembangkan semangat belajar; dan 5) pelibatan peserta didik dalam perencanaan dan pengelolaan pembelajaran. Sedangkan beberapa kekurangan tipe pembelajaran picture and picture ini antara lain: 1) memungkinkan menggunakan waktu pembelajaran yang cukup lama; 2) memungkinkan sebagian peserta didik pasif; 3) memungkinkan akan terjadinya kekacauan atau ketidakkondusifan kelas; dan 4) membutuhkan media dan fasilitas pembelajaran sebagai penunjang.

\section{Make a Macth}

Menurut Suprijono (2010: 94) tipe pembelajaran make a match merupakan tipe pembelajaran yang menggunakan media kartu yang terdiri atas kartu yang berisi pertanyaan dan kartu yang berisi jawaban. Dalam tipe pembelajarana ini, peserta didik disuruh untuk menemukan atau mencocokan setiap pertanyaan dan jawaban pada setiap kartu. Kurniasih dan Sani (2015:56) menyebutkan beberapa kelebihan dan kelemahan tipe pembelajaran make a macth. Di antara kelebihan tipe pembelajaran ini: 1) dapat menciptakan kondisi pembelajaran yang menyenangkan yang aktif; dan 2) mendorong peserta didik untuk bekerja sama dengan rekannya dalam menemukan pertanyaan dan jawaban yang tepat. Sedangkan kelemahan tipe pembelajaran ini di antaranya: 1) masih memerlukan bimbingan dan arahan guru dalam setiap kegiatannya; 2) memungkinkan penggunaan waktu yang relatif lama; 3) membutuhkan persiapan awal dalam memenuhi bahan dan alat yang diperlukan; dan 4) memungkinkan suasana belajar yang tidak kondusif dan mengganggu kelas lain, sehingga guru harus bisa mengendalikan kelas.

\section{Student Facilitator and Explaining}

$\begin{array}{ccc}\text { Huda } & \text { (2014: } & \text { 228) } \\ \text { mengemukakan } & \text { bahwa }\end{array}$ pembelajaran student facilitator and explaining (SFE) merupakan rangkaian penyajian materi ajar yang diawali dengan penjelasan secara terbuka, memberi kesempatan peserta didik untuk menjelaskan kembali kepada rekanrekannya, dan diakhiri dengan penyampaian semua materi kepada siswa. Sedangkan Aqib (2015: 28), menegaskan bahwa tipe student 
facilitator and explaining merupakan tipe pembelajaran yang memfasilitasi peserta didik untuk mempresentasikan ide/pendapat pada rekan atau peserta lainnya. Pada tipe pembelajaran ini peserta didik belajar bicara untuk menyampaikan ide dan gagasan.

Huda (2014: 229) juga mengemukakan kelebihan dan kelemahan tipe pembelajaran student facilitator and explaining ini. Di antara kelebihan tipe ini antara lain: 1) membuat materi lebih jelas; 2) menumbuhkan daya ingat peserta didik karena dilakukan dengan demonstrasi; 3) melatih peserta didik menjadi guru, karena peserta didik diberikan kesempatan menjelaskan kembali apa yang telah dijelaskan guru; 4) memacu peserta didik untuk menjadi yang terbaik dalam menjelaskan materi; dan 5) guru dapat mengetahui keterampilan berbicara peserta didik dalam menyampaikan gagasan. Sedangkan kelemahan tipe pembelajaran ini antara lain: 1) peserta didik yang pemalu dan pendiam akan mengalami kesulitan dalam menjelaskan materi; 2) tidak semua peserta didik memiliki giliran dalam menjelaskan materi; 3) persamaan pendapat menimbulkan keterampilan dan kreatif yang sempit; dan 4) memungkinkan peserta didik mengalami kesulitan dalam memetakonsepkan materi.

\section{Role Playing}

Menurut Huda (2014: 208) role playing merupakan salah satu tipe pembelajaran kooperatif yang mengedepankan imajinasi peserta didik untuk memerankan dan menghayati menjadi seorang tokoh tertentu. Dalam penerapannya tipe pembelajaran ini biasa dimainkan dalam kelompok. Misalnya dalam persoalan penanganan kasus pidana, peserta didik akan dibagi untuk bermain peran sebagai jaksa, hakim, terdakwa, saksi, dan sebagainya. Beberapa kelebihan tipe role playing menurut Huda (2014: 210) antara lain: 1) menumbuhkan daya ingat peserta didik, karena dilakukan seolah-olah peserta didik mengalami langsung; 2) membuat pembelajaran menyenangkan; dan 3) menumbuhkan rasa kebersamaan di antara peserta didik. Sedangkan kekurangan tipeodel ini antara lain: 1) membutuhkan waktu yang relatif lama; 2) peserta didik akan mengalami kesulitan mamainkan peran jika tidak dilatih dengan baik; 3) membutuhkan persiapan yang benar-benar matang; dan 4) tidak semua materi bisa diterapkan dengan menggunakan tipe role playing.

Pada dasarnya semua tipe dari model pembelajaran kooperatif adalah baik dan memiliki kelebihan dan kekurangannya masing-masing. Namun, dalam penggunaan model pembelajaran kooperatif perlu disesuaikan dengan materi serta kompetensi pembelajaran yang hendak dicapai. Selain itu, ketersediaan media, alat, sarana dan prasarana, serta kemampuan guru dalam mempersiapkan, melaksanakan, dan mengelola pembelajaran juga sangat berpengaruh terhadap keberhasilan dalam kegiatan pembelajaran 
dengan menggunakan model pembelajaran kooperatif ini.

\section{Model Pembelajaran Kooperatif yang Tepat dalam Pembelajaran PPKn untuk Penanaman Karakter Peserta Didik di Sekolah}

Pendidikan Pancasila dan

Kewarganegaraan (PPKn) di tingkat persekolahan memiliki tujuan mebentuk peserta didik menjadi pribadi yang cerdas dan baik (to be smart dan good citizen) yang meliputi penguasaan pengetahuan (knowledge), sikap dan nilai (attitudes and values), keterampilan (skills) (Ikhtiarti, Adha, \& Yanzi, 2019). Selain itu, tujuan PPKn secara khusus juga menjadikan peserta didik agar mampu menjunjung nilai-nilai Pancasila dan UUD Negara Republik Indonesia Tahun 1945, menjadi pribadi yang berpikir kritis, berperan aktif, rasional, kreatif, serta menjadi pribadi yang bertanggung jawab, baik dalam lingkungan keluarga, sekolah, maupun masyarakat.

Dari tujuan mata pelajaran PPKn di atas dapat diketahui bahwa PPKn sebagai mata pelajaran yang semata-mata diajarkan begitu saja, tanpa adanya perubahan perilaku peserta didik. PPKn mengemban misi sebagai salah satu bentuk pendidikan nilai, moral dan karakter kewarganegaraan Indonesia (Angraini, 2017; Suradi, 2020). Selain itu, ditinjau dari kajian materi, PPKn memiliki cakupan materi yang sangat luas. Berbagai kajian dari kajian mengenai pemerintahan, politik, tata negara, demokrasi, serta kajian sosial lain, sehingga dalam mencapai tujuan mata pelajaran PPKn tersebut juga diperlukan strategi pembelajaran yang relevan dan mempermudah guru. Salah satu caranya yaitu dengan menerapkan pembelajaran kooperatif, karena model pembelajaran ini sangat dinamis dan fleksibel sesuai dengan kajian dan persoalan dalam mata pelajaran PPKn yang luas dan kompleks.

Secara umum, sebelum menggunakan model pembelajaran kooperatif ada berbagai pertimbangan yang harus diperhatikan agar penggunaan model kooperatif efekrif dalam pembelajaran (Lasmana \& Natajaya, 2014). Di antara pertimbangan yang perlu diperhatikan terkait penggunaanya model pembelajaran, yaitu: 1) positif interdependence; 2) pengembangan hubungan yang baik antarpeserta didik; 3) keberhasilan kelompok dicapai dengan kerja keras dan peran dari para anggota kelompoknya; 4) pengembanagan kemampuan dan keterampilan peserta didik; dan 5) menjadikan peserta didik berpikir dan bekerja secara efektif dan efisien.

Pertama, interdependence merupakan keadaan yang memungkinkan penggunaan model pembelajaran kooperatif dapat menimbulkan beberapa kemajuan yang baik bagi peserta didik setelah mengikuti pembelajaran. Kemajuan-kemajuan peserta didik tersebut dapat berupa prestasi belajar, bertambahnya pengetahuan dan pemahaman, serta kemampuan dalam bersikap dan bertindak sebagai individu dan sebagai bagian dari kelompok. 
Kedua, pengembangan hubungan yang baik antarpeserta didik. Sesuai dengan karakteristiknya, model pembelajaran kooperatif merupakan salah satu model yang didesain dan dirancang dengan membagi peserta didik dalam beberapa kelompok kecil. Pembagian ini biasanya bersifat heterogen. Oleh karena itu, dengan pelaksanaan pembelajaran yang dilaksanakan dengan pembagian ke dalam kelompok-kelompok kecil, peserta didik akan mampu mengembangkan kemampuan bekerja sama dalam sebuah tim, disiplin, bertanggung jawab, dan berpikir kritis dalam memecahkan sebuah permasalahan bersama kelompoknya, sehingga terbentuk sebuah hubungan antarpeserta didik yang baik dan harmonis. Hal tersebut sesuai dengan pendapat Arianti (2015) yang menjelaskan bahwa pembelajaran yang menggunakan model kooperatif atau yang biasa disebut dengan cooperative learning memfokuskan dan menitikberatkan pada peran dan partsipasi aktif peserta didik, kreativitas peserta didik, dan hubungan dan komunikasi antarpeserta didik, keterampilan kerja sama antarperserta didik, baik kerja sama di dalam kelompoknya maupun kerja sama dengan kelompok lain, dan komunikasi antarpeserta didik.

Ketiga, keberhasilan kelompok dicapai dengan kerja keras dan peran dari para anggota kelompoknya. Model pembelajaran kooperatif yang menekankan kerja sama dalam kelompok kecil tidak bergantung hanya pada satu atau dua peserta didik. Keberhasilan dalam pelaksanaan pembelajaran, yang dijalankan dengan diskusi dan pemecahan masalah, sangat menuntut peran dan partisipasi oleh setiap anggota kelompok. Dalam hal ini model pembelajaran kooperatif akan melatih dan membiasakan peserta didik untuk bermusyawarah, berdiskusi, dan memecahkan masalah dengan anggota lain dalam kelompoknya. Setiap ego dan rasa individu, serta ingin menang sendiri dalam kelompok akan hilang karena prinsip tujuan dan partisipasi bersama.

Kempat, pengembanagan kemampuan dan keterampilan peserta didik. Guru yang dijadikan sebagai fasilitator dan pengarah menjadikan pembelajaran dengan menggunakan model kooperatif menjadi lebih terpusat pada peserta didik. Hal ini tentunya menimbulkan dampak yang sangat baik bagi mental dan kemampuan dalam bertindak pada peserta didik. Dalam pembelajaran menggunakan model kooperatif, peserta didik akan dibiasakan dan dilatih untuk memiliki keterampulan berbicara, menjelaskan materi pembelajaran di depan kelas, berpikir kritis, berdiskusi, menyanggah dan memperkuat pendapat orang lain, bekerja sama dalam memecahkan masalah, serta membiasakan peserta didik dalam merencanakan dan menentukan konsep atau skema materi yang sederhana. Hal tersebut sesuai dengan pendapat Tristiantari \& Sumantri (2016) bahwa kemampuan dan keterampialn yang berupa prestasi akademik serta, menghargai perbedaan, serta 
tumbuhnya kemampuan sosial peserta didik dapat dicapai dengan pembelajaran yang menggunakan model pembelajaran kooperatif.

Kelima, menjadikan peserta didik berpikikir dan bekerja secara efektif dan efisien. Kemampuankemampuan peserta didik yang telah dilatih dalam merencanakan matei secara sederhana akan menmbuat peserta didik dalam kondisi dimana mereka menginginkan pemecahanpemecahan masalah yang baik dan tidak rumit. Para peserta didik akan dilatih untuk itu sehingga, mereka berpikir dan menemukan cara-cara yang dapat memberikan solusi dengan baik dan sederhana.

Bertolak dari yang telah dikemukakan di atas, pada dasarnya semua tipe dari model pembelajaran kooperatif adalah baik, dan memiliki kelebihan dan kekurangannya masing-masing sesuai dengan materi apa yang hendak disampaikan oleh guru. Hal tersebut sesuai dengan pendapat Fathurrohman (2015:31) yang menegaskan bahwa penggunaan model pembelajaran yang baik memiliki ciri-ciri atau karakteristik antara lain:; 1) melibatkan intelektual-emosional peserta didik, seperti mengalami, berbuat, merasakan, dan bertindak; 2) keikutsertaan peserta didik secara aktif; 3) menempatkan guru sebagai fasilitator, motivator, dan mediator; dan 4) model pembelajaran didukung penggunaan media, alat, serta sarana dan prasarana yang ada.

Dari beberapa pendapat yang telah dijelaskan di atas dapat disimpulkan bahwa berkaitan dengan penggunaan model pembelajaran kooperatif dalam pembelajaran Pendidikan Pancasila dan Kewarganegaraan (PPKn), ada beberapa hal yang perlu diperhatikan mengenai penggunaan model pembelajaran kooperatif yang tepat dan relevan dengan karakteristik mata pelajaran PPKn. Model pembelajaran kooperatif yang diterapkan dalam pembelajaran PPKn harus sebagai berikut.

1) Memiliki prosedur yang mengorganisasikan pemahaman serta pengalaman belajar peserta didik. Hal ini dikarenakan dalam kajian mata pelajaran PPKn ada kajian ilmu sosial, yang berkaitan dengan bagaimana peserta didik harus bersikap dan bertindak, serta menemukan solusi dalam menghadapi setiap masalah dalam kehidupan nyata. Dengan kata lain, model pembelajaran kooperatif yang digunakan dalam pembelajaran PPKn harus terintegrasi dengan lingkungan peserta didik.

2) Mampu diintegrasikan dengan fenomena-fenomena sosial atau fenomena kewarganegaraan, sehingga mampu membuat peserta didik memilki dan memahami nilai-nilai demokrasi, toleransi, kebebasan berpendapat, musyawarah, kerja sama, dan sebagainya.

3) Penggunaan model pembelajaran kooperatif dalam pembelajaran harus logis dan memiliki landasan berpikir yang konkret.

4) Penerapan model pembelajaran kooperatif dalam pembelajaran PPKn mencakup konteks akademik sendiri harus 
disesuaikan dengan materi dan kompetensi yang hendak dicapai, serta mampu memaksimalkan bakat, minat, dan potensi peserta didik.

5) Model pembelajaran kooperatif yang digunakan dalam pembelajaran PPKn harus dapat mengarahkan peserta didik bersikap serta memiliki pola pikir ilmiah (scientific) dan berpikir kritis.

Dalam pelaksanaan pembelajaran ada beberapa tipe dari pembelajaran kooperatif yang dianggap sesuai dengan kajian serta pengembangan sikap pada mata pelajaran PPKn. Misalnya, untuk mendorong peserta didik bersikap dan menanamkan nilai-nilai tanggung jawab, toleransi, melatih mengemukakan pendapat atau keterampilan berbicara, menghargai pendapat, dan bersikap demokratis seorang guru dapat memilih model pembelajaran kooperatif tipe student facilitator and explaining. Tipe model kooperatif ini sangat sesuai apabila diterapkan dalam materi yang menekankan pada pengetahuan dan pemahaman peserta didik. Biasanya pada tahap pelaksanaan model ini peserta didik akan diberikan kesempatan menjelaskan materi pembelajaran di depan kelas.

Selanjutnya, ketika guru menginginkan penanaman dan pembentukan nilai-nilai tanggung jawab, guru dapat menerapkan model pembelajaran kooperatif jenis tipe role playing. Dalam penggunaan tipe pembelajaran ini membutuhkan simulasi atau peragaan, agar para peserta didik dapat memainkan peran mereka, seolah-olah mereka mengalami peristiwa secara langsung. Selain, sebagai salah satu bentuk penanaman nilai tanggung jawab, guru dapat menggunakan tipe role playing ini sebagi penanaman karakter kerja sama dan disiplin. Namun, kembali lagi bahwa keberhasilan penggunaan model pembelajaran kooperatif sebagai strategi penanaman karakter peserta didik, secara umum dipengaruhi oleh perencanaan, pelaksanaan, dan hasil evaluasi. Pencapaian tujuan pembelajaran sangat dipengaruhi oleh kejelian guru dalam mengelola dan memilih model pembelajaran yang hendak dipakai, yakni dengan mempertimbangkan beberapa hal tertentu. Begitu juga dengan penggunaan tipe model pembelajaran kooperatif dalam pembelajaran PPKn, tentunya juga disesuaikan dengan tujuan pembelajaran dan kompetensi mata pelajaran PPKn yang akan dicapai, serta keterampilan peserta didik yang hendak dikembangkan.

\section{PENUTUP}

Model pembelajaran kooperatif memiliki tujuan yaitu membantu peserta didik dalam membentuk serta mengembangkan pengetahuan, sikap, dan perilaku sesuai kebutuhan dalam kehidupan nyata. Melaluinya, peserta didik akan bertambah kualitas diri, baik secara pemahaman maupun sikap dan aksi dalam kehidupan seharihari. Pola interaksi yang terjadi dalam model pembelajaran kooperatif yang cenderung mengedepankan kerja sama, toleransi, saling menghargai, dan 
mufakat. Model pembelajaran ini akan melatih peserta didik untuk membiasakan dirinya bersikap dan berperilaku sesuai dengan nilainilai karakter yang luhur.

Pada dasarnya semua tipe dari model pembelajaran kooperatif adalah baik, dan memiliki kelebihan dan kekurangannya masing-masing. Namun, dalam penggunaan model pembelajaran kooperatif dalam pembelajaran PPKn perlu disesuaikan dengan materi serta kompetensi pembelajaran yang hendak dicapai. Selain itu, ketersediaan media, alat, sarana dan prasarana, serta kemampuan guru dalam mempersiapkan, melaksanakan, dan mengelola pembelajaran juga sangat berpengaruh terhadap keberhasilan dalam kegiatan pembelajaran PPKn. Ada beberapa hal yang perlu diperhatikan mengenai penggunaan yang tepat model kooperatif yang relevan dengan karakteristik mata pelajaran PPKn, di antaranya: 1) memiliki prosedur yang mengorganisasikan pemahaman serta pengalaman belajar peserta didik; 2) mampu diintegrasikan dengan fenomenafenomena sosial atau fenomena kewarganegaraan; 3) penggunaan model pembelejaran kooperatif dalam pembelajaran PPKn harus logis dan memiliki landasan berpikir yang konkret; dan 4) penerapan model pembelajaran kooperatif dalam pembelajaran PPKn mencakup konteks akademik dan harus disesuaikan dengan materi dan kompetensi yang hendak dicapai serta mampu mendorong peserta didik untuk berperan aktif, berpikir kritis, memaksimalkan bakat, minat, serta potensi peserta didik.

\section{UCAPAN TERIMA KASIH}

Dengan selesainya tulisan ini, penulis sangat bersyukur kepada Allah Swt. Selanjutnya, penulis mengucapkan terima kasih kepada Dr. Marzuki, M.Ag. selaku dosen di prodi PPKn PPs Universitas Negeri Yogyakarta yang banya memberikan dalam hal penulisan karya ilmiah sehingga penulis berusaha untuk menulis secara benar. Tulisan ini sebagai bukti dari hasil bimbingan beliau.

\section{DAFTAR PUSTAKA}

Akçay, N. O. (2016). Implementation of Cooperative Learning Model in Preschool. Journal of Education and Learning, 5(3), 83-93. Retrieved from https://eric.ed.gov/?id=EJ1100 $\underline{961 .}$

Akbal, M. (2017, 29 Oktober). Pendidikan Kewarganegaraan dalam pembangunan karakter bangsa. Prosiding Seminar Nasional Himpunan Sarjana Ilmu-ilmu Sosial dengan tema "Pendidikan Ilmu-Ilmu Sosial Membentuk Karakter Bangsa dalam Rangka Daya Saing Global" di Makassar (Vol. 2, 485-493). Retrieved from https://ojs.unm.ac.id/PSNHSIS/article/view/4084.

Angraini, R. (2017). Karakteristik media yang tepat dalam pembelajaran pendidikan kewarganegaraan (PKn) sebagai pendidikan nilai. Journal of Moral and 
Civic Educ, 1(1), 14-24. DOI: 10.24036/8851412020171116.

Arianti, T. P. (2015). Penerapan model pembelajaran kooperatif tipe TGT dalam pembelajaran subtema hewan di sekitarku untuk meningkatkan hasil belajar siswa di Sekolah Dasar. Jurnal Penelitian Pendidikan Guru Sekolah Dasar, 3(2), 358-368. Retrieved from https://www.neliti.com/id/publ ications/253726/penerapanmodel-pembelajarankooperatif-tipe-tgt-dalampembelajaran-subtema-hewa.

Aqib, Z. (2015). Model-model, media dan strategi pembelajaran kontekstual (inovatif). Bandung: Yrama Widya.

Bodsworth, H., \& Goodyear, V. A. (2017). Barriers and facilitators to using digital technologies in the Cooperative Learning model in physical education. Physical Education and Sport Pedagogy, 22(6), $\quad$ 563-579. DOI:

10.1080/17408989.2017.12946 72.

Djamarah, S. B. (2008). Strategi belajar mengajar. Bandung: Rineka Cipta.

Dyson, B., \& Casey, A. (2016). Cooperative learning in physical education and physical activity: A practical introduction. New York: Routledge.

Fathurrohman, M. (2015). Modelmodel pembelajaran inovatif. Yogyakarta: Ar-Ruzz Media.

Hamisa, W., \& Murdiyono, M. (2018). Peran PKn sebagai pendidikan politik dalam membangun sikap demokratis dan partisipasi siswa dalam organisasi di SMA. Harmoni Sosial: Jurnal Pendidikan IPS, 5(2), 192-201. DOI: https://doi.org/10.21831/ hsjpi.v5i2.11205.

Hasan, H. S. (1996). Pendidikan ilmu-ilmu sosial. Bandung: FIPS IKIP Bandung.

Huda, M. (2014). Model-model pengajaran dan pembelajaran. Yogyakarta: Pustaka Pelajar.

Ikhtiarti, E., Adha, M. M., \& Yanzi, H. (2019). Membangun generasi muda smart and good citizenship melalui pembelajaran ppkn menghadapi tantangan revolusi industri. In: Seminar Nasional Pendidikan FKIP 2019, 03 Januari 2019, FKIP Universitas Lampung. Retrieved from http://repository.lppm.unila.ac. id/id/eprint/13316.

Isjoni. (2009). Cooperative learning mengembangkan kemampuan belajar bekelompok. Bandung: Alfabeta.

Isjoni. (2010). Cooperative learning efektivitas pembelajaran kelompok. Bandung: Alfabeta.

Kementerian Pendidikan dan Kebudayaan. (2014). Buku guru Pendidikan Pancasila dan Kewarganegaraan untuk SMA/MA/SMK/MAK. Jakarta: Kementerian Pendidikan dan Kebudayaan.

Kurniasih, I. \& Sani, B. (2015). Ragam pengembangan model pembelajaran untuk meningkatkan profesionalitas guru. Jakarta: Kata Pena. 
Leasa, M., \& Corebima, A. D. (2017, January). The effect of numbered heads together (NHT) cooperative learning model on the cognitive achievement of students with different academic ability. In Journal of Physics: Conference Series (Vol. 795, No. 1, p. 012071). IOP Publishing.

DOI:10.1088/17426596/795/1/012071.

Maman, M., \& Rajab, A. A. (2016). The implementation of cooperative learning model" number heads together"(" NHT") in Improving the students' ability in reading comprehension. International Journal of Evaluation and Research in Education, 5(2), 174-180. Retrieved from https://eric.ed.gov/?id=EJ1108 $\underline{535}$.

Martati, B. (2010). Metodelogi pembelajaran pendidikan kewarganegaraan. Bandung: Genesindo.

Muhibbin, A., \& Sumarjoko, B. (2016). Model pembelajaran Pendidikan Kewarganegaraan berbasis isu-isu kontroversial di media massa untuk meningkatkan sikap demokrasi mahasiswa dan implikasinya bagi masyarakat madani. Jurnal Pendidikan Ilmu Sosial, 26(1), 1-10. DOI: $10.2317 /$ ipis.v26i1.2035.

Pangalila, T. (2017). Peningkatan civic disposition siswa melalui pembelajaran Pendidikan Kewarganegaraan (PKn). Jurnal Pendidikan Kewarganegaraan, 7(1), 91-
103.

DOI: $10.20527 /$ kewarganegara an.v7i1.3553.

Rahman, A., Ahmar, A., \& Rusli, R. (2016). The influence of cooperative learning models on learning outcomes based on students' learning styles. World Transactions on Engineering and Technology Education, 14(3), 425-430. Retrieved from https://papers.ssrn.com/sol3/pa pers.cfm?abstract_id=2924441

Shoimin, A. (2014). 68 model inovatif dalam kurikulum 2013. Yogyakarta: Ar-Ruzz Media.

Slavin, E. R. 2011. Cooperative learning teori, riset dan praktik. Terjemahan dari buku asli: "Cooperative Learning: Theory, Research, and Practice". Bandung: Nusa Media. Cetakan ke-19.

Solihatin, E. (2013). Strategi pembelajaran PPKn. Jakarta: Bumi Aksara.

Sudharmini, L. S., Lasmawan, I. W., Natajaya, I. N. (2014). Pengaruh model pembelajaran kooperatif tipe jigsaw terhadap motivasi belajar dan hasil belajar IPS siswa kelas V Sekolah Dasar gugus IV Jimbaran, Kuta Selatan. Jurnal Pendidikan Dasar. Retrieved from http://119.252.161.254/ejournal/index.php/jurnal_pend as/article/view/.

Suprijono, A. (2010). Cooperative learning. Yogyakarta: PustakaPelajar.

Suradi, L. (2020). Pendidikan kewarganegaraan sebagai 
pendidikan nilai dan pendidikan hukum dalam mewujudkan warga negara yang cerdas dan baik (smart and good citizen). SUPREMASI: Jurnal Pemikiran, Penelitian Ilmuilmu Sosial, Hukum dan Pengajarannya, 14(2), $\quad$ 112121. Retrieved from http://103.76.50.195/supremasi /article/viewFile/13143/7622.

Surapranata. (2010). Model-model pembelajaran. Jakarta: Kementrian Pendidikan Nasional.

Trianto. 2010. Mendesain model pembelajaran inovatif progesif. Jakarta : Bumi Aksara.
Tristiantari, N. K. D. \& Sumantri, I. M. (2016). Model pembelajaran kooperatif integrated reading composition berpola lesson study meningkatkan keterampilan membaca dan menulis. Jurnal Pendidikan Indonesia, 5(2), 204-211. DOI: $10.23887 / \mathrm{jpi}-$ undiksha.v5i2.8493.

Wahab, A. A. (1995). Pendidikan Pancasila dan Kewarganegaraan (PPKn). Bandung: Kementerian Pendidikan dan Kebudayaan. 